\title{
MAGAZINE OF INTELLECTUAL COMMUNITY IN BUILDING A NEW NATION, HAYAT (1926-1929)
}

\author{
Çilem Tuğba Akdağ' ${ }^{1}$ Ebru Davulcu² \\ ${ }^{1}$ Res. Asst. Dr., Erciyes University, Faculty of Communication, Journalism Department, \\ takdag@erciyes.edu.tr \\ ${ }^{2}$ Asst. Prof. Dr., Erciyes University, Faculty of Communication, Journalism Department, \\ eakbaba@erciyes.edu.tr
}

\begin{abstract}
The magazine Hayat published 146 magazines between $2^{\text {nd }}$ of December 1926 and $30^{\text {th }}$ of 1929 three years after the Proclamation of the Republic in Ankara which was the new seat of government. The significant characters of the time such as Köprülüzade Mehmet Fuat, Fazıl Ahmet, Mustafa Şekip (Tunç), Mehmet İzzet, Ahmet Refik and Necmettin Sadık, known as the writers close to the new regime, wrote in the magazine which had been directed by Mehmet Emin (Erişirgil), Nâfî Atuf (Kansu), Faruk Nafiz (Çamlıbel) from time to time. The motto of the magazine was the quotes of Nietzsche: "To the life, always to the life... Let's bring more the world to the life!" The magazine Hayat had a significant role on imbedding the intellectual and cultural bones of the Republic ideology by mediating on the recognition of the new regime. Hayat, aiming to increase the attention of the youth to the science, had a desire to see an intellectual community who had the ability to see new tendencies and to think over the fact. In his interview published in the first magazine, Mehmet Emin stated that Hayat did not belong to anyone. Hayat belonged to the whole intellectual community and would be encouraged by their tendencies and would tell their common ideals. One could see that the topics being a part of building a new nation such as nationalism, progress, modernization, improvement in science and economics with the topic of reformism had been discussed on an intellectual basis. In this study under the qualitative historical research, the articles chosen over the themes in question have been reviewed and how the Republic regime and ideals were build has been investigated.
\end{abstract}

Keywords: The Magazine Hayat, the Republican Ideology and Reformism, Nation Building

\section{INTRODUCTION}

Following the abolition of Sultanate on 1 November 1922 and with the proclamation of the Republic on 29 October 1923, reforms had begun to proceed within all areas with their political, social, economic, cultural and legal dimensions. Through the reforms, a modern nation was aimed to be established. Veteran Soldier Mustafa Kemal stated that they were intended to found a new state by uttering that "A ruined state on the verge of a cliff... Bloody buffets with all sorts of enemies... A war of years... And then, a new country that is respectfully known inland and outland, a new society, a new state and continuous reforms in order to achieve all of them... Here is a short signification of general Turkish revolution..." within the scope of 
opening speech of fourth general assembly of Republican People's Party (Atatürk'ün Söylev ve Demeçleri, 1989, p.398). The aim of the reforms that were performed was modernization of society by taking Western civilizations as an example. Veteran Soldier Mustafa Kemal explained that the basic precept of his reforms was to transmit Turkish society to the level of a completely modern and a fully and fairly civilized community (Gökberk, 1997, p.44). Media was one of the most important intermediaries of the parties that had procured the reforms. Media, within the scope of this period, did its duty of adopting the reforms on society by transferring the instructions coming from the political power without a doubt to the community (Topuz, 2003, p.162; Koloğlu, 2006, p. 118).

One of the journals that were published within the borders of this duty was the journal of Hayat. The journal of Hayat was published between the dates of 2 December 1926 and 30 December 1929. The aim of it was to help the nation to pay its debt back to the revolution, in turn of the fact that this essential revolution had created a self-contained Turkey with a safe position. This help was in relation to equipping the nation, especially the Youngers, with genuine science and knowledge. Hayat was pursuing a way for awakening reverence in youth with genuine science and knowledge mentality and a way for increasing the relationship of youth with science and knowledge. It had a wish of making the youth observe the incidents and think on them. The assistant of Hayat fort his cause was intelligentsia (Mehmet Emin, 2 Kanun-u Evvel 1926, p. 1-2). There are several studies that were previously performed in relation to the journal of Hayat. These studies include various thesis such as "Literary Content in the Journal of Hayat" which was written by Mehmet Günes, "Analysis of Language and Literary Works in the Journal of Hayat" that was written by Ece Avci, "The Journal of Hayat 4, 5, 6. Volumes and New Regulation" that was written by Oğuz Şenses, "Analytic Index of the Journal of Hayat and Islamic Analysis" that was prepared by Zeynep Rumeysa Cora. These studies focused on literary or religious analysis of aforementioned journal.

Within the scope of this study that is titled as "Hayat (1926-1929), the Journal of Intelligentsia in the Foundation of a New Nation", it is analyzed that how Republican regime and ideals were imprinted on minds on the basis of the importance of Hayat as an intermediary for introduction of the new regime in terms of building the ideology of Republic on intellectual and cultural grounds. Within the context of the study which is qualitative historical, firstly, information about the journal of Hayat is given, and then articles of the journal in relation to certain titles such as reforms and scientific progress, mobilization of system of education, the place of intellectuals in terms of reforms, revolution culture and the ideal of a new generation were evaluated. The study is restricted to first 146 issues of the journal of Hayat that constitute integrity, and new contexture of five issues that were published in the year of 1930 is not analyzed. Except for 134th issue of the journal of Hayat, all issues were obtained from Istanbul Metropolitan Municipality's Ataturk Library and Hakkı Tarık Us Collection.

\section{ABOUT THE JOURNAL}

The journal of Hayat, 146 issues of which were published between the dates of 2 December 1926 and 30 December 1929, was issued as five more issues in 1930s in a way it was different from its previous version in terms of form and content. Management of the journal was undertaken by Mehmet Emin for the first 75 issues, by Nâfi Atuf for 76th, 22th and 78th issues and by Fâruk Nâfiz between the issues of 79 and 146 . The address of the journal, executive Office of which was in Ankara, was stated as "the apartment next to the Ministry of Education on Istanbul Street in Ankara". There was also another Office of the journal in Istanbul. Upon 137th issue, the address of executive Office was only given as Ankara. Within the scope of 140th issue, it was announced under the title of "To our Readers" that the journal was completely transported to Ankara (Hayat, 30 September 1929, p.15). Copy price of the journal was 10 piastres for the first 58 issues; 15 piastres after 58th issue. Along with this, no information in relation to copy price was given after the printing of 135th issue. The statement of that the annual price of the journal was 375 piastres were placed. In 143th issue, the price was increased as 376 piastres, and it was discounted to 365 piastres in 145th issue. Within the scope of 139,142, 144 and 146th issues of the journal, no information in relation to subscription was given. The journal turned its readers into subscribers. The price of subscription was changeable. The price of subscription for the first 11 issues was 5 Liras with annual post, and was 5 dollars in foreign countries. Subscription price of the journal for foreign countries each year was 4 dollars for the issues between 12 th and $19^{\text {th }}$, then it was risen to 5 dollars for the issues between 20th and 57 th and lastly 7,5 dollars for the issues between 58th and 133th. By the print of the 135th issue, information in relation to the prices in foreign countries was removed.

The journal of Hayat was published once a week for the first 133 issues, and by the 135th issue, it was published as once in fifteen days. The journal had a break only for one time, published its 135th issue 24 days after its 134th issue, on 15 July 1928. The journal had a change in terms of its term within the scope of its 135th issue. This change was presented under the main title of "Hayat and Publications", under the sub- 
title of "New Form of Hayat". Within the context of the article, it was stated that publication was procured in order to "become an effective factor in the name of science and art" for approximately three year, each kind of sacrifices were performed in this direction, and an important hole in the country was tried to be filled by a solely single figure. Additionally, in the following lines of the article, it was stated that a formal change was embodied within the scope of the journal by taking advantage of the experiences in the direction of publishing Hayat still stronger and younger that its form of the last three years during which the aim of becoming the most useful journal for the circle of science and art had been performed. Later on, it stated that the two-or-three-week break which was taken before the publication of the 135th issue shall be considered as an effort of acceleration for an innovative movement (Hayat, 15 July 1929, p.23).

It is also seen that the journal was published a few days before or after its publication day. 21st issue was published on 23 April 1927 with a 2-day delay, 38th issue past published on 18 August 1927as 1 day earlier than publication day, 142nd issue was published on 29 October 1929 as 1 day earlier that the publication day. The reason why 142 nd issue was published on 29 October was stated as Republic day within the scope of 140 th issue. In the publication, it was announced that a magnificent copy will be published due to Republic Day and precious readers would meet various valuable articles within the scope of this issue (Hayat, 30 September 1929, p.15). The journal of Hayat completed its broadcast life, which began with Arabic alphabet, with Latin letters. Firstly, within the scope of 79th issue of the journal, the digits that were used within the texts and for indicating page numbers, price, date, number and issue number were translated into the new language. Moreover in 86th issue, three introduction articles were titled in English and Latin letters begun to be used. These articles were White papers of three books with the titles of "The Persian Gulf: An Historical Sketch", "Uncensored Dardanelles" and "Some Chapters from the Historical Writings of Fray Bernardino Sahagun" (Hayat, 19 July 1928, p.162). It is observed that the first piece with the use of Latin letters was within the content of 90th issue of the journal. This piece was the poem of Fâruk Nâfiz which was titles as "Poems on the Sand" (Fâruk Nâfiz, 19 August 1928, p.232). In the same page, on the upper side of the poem, within the article that addresses as "To Hayat Reader", it is stated that the journal will provide information in order to make the readers learn and get accustomed to the new language. Right under the writing, consonant and sonant letters along with a couple of sign were presented to the reader (Hayat, 19 August 1928, p.232).

After the 90th issue, it is seen that each issue of the journal gave a section for one or two articles that were written with Latin alphabet. By the 96th issue, forewords ${ }^{1}$ on cover pages, and in 96th issue a couple of content were written in Latin, while all of the titles turned into new language by 97th issue. A part of the articles that were published beginning from 99th issue and complete of the issues beginning from 105th issue were observed as written with Latin alphabet. Additionally, it is also observed that the number of pages was also changed within the scope of the journal which was published as black and White. The first 132 issues of the journal consisted of 20 pages. Along with this, all of the copies between the issues of 73, 75, 83. and 135 and 141 consisted of 24 pages and between the copies between 133th and 146th issues consisted of 16 pages, moreover 142nd issue was published as including 32 pages. On the cover of the first issue of Hayat magazine, the name of the journal was placed with bold points in the upper and middle part. Right under the name of "Hayat", the words of Nietzsche "To life, always to the life... Let's add more life to the World!" were placed. On the right side of the name of the journal, the name of the manager of the journal was placed in a bilinear rectangular box and in the middle, information on executive Office, and under, the address of Istanbul Office were written. When we look at upper left section of the journal, moreover, again in a bilinear rectangular box, copy price of the journal and subscription information were written. Right under the information, the facts that for subscription and announcement operations, Istanbul or Ankara branch shall be consulted and center of editorial department was located in Ankara were stated. Under all these information, a horizontal line is scratched, and under this line, on the right side the number of issue, in the middle place and date, on the left, volume number are written with two lines.

After the second issue, there wasn't any information in relation to the manager within the scope of superscription. Information in relation to the manager and the printing house is given on the right bottom side of the last page. In the bilinear rectangular box on the left, the place to apply for advertisements and subscription transaction were changed as solely Istanbul branch. During the first 96 issues, the superscription that was published in the same from was given through Latin alphabet beginning from the 97th issue. For this reason, it is observed that the part through which the information was given had also gone through a change. According to this change, price and subscription and advertisement information were given within the box on the right, and the address of the executive Office was given on the left.

${ }^{1}$ The first interview in the journal of Hayat with Latin words was "Dağ Yolu" which was prepared by Mehmet Emin in 95th issue. See. Mehmet Emin, "Dağ Yolu”, Hayat, 20 September 1928, V. 4, Issue: 95, p.325. 
Information that used to be given between two lines on the bottom, moreover, changed as volume, date, place and number of issue from right to left. In the 135th issue, the superscription was also changed. The name of the journal was written in lower cases on the left. Moreover, on the right upper side, the statement of Nietzsche which is the motto of the journal was written, and right under it, volume, date and number of issue were given. This part of the title was separated from the rest of the cover with a bold line. Information on executive Office and prices that were current in superscription until this issue were moved to the last page of the journal. Information on subscription and advertisement was completely removed. Within 139th issue, the typeface of the name of the journal was changed. A logo was added to the superscription. It is seen that, in the logo, a White dove is preparing to carry the star in its mouth up, in a circle upper ends of which are open. This logo represents the idea that Turkish nation and ideals will be freed from their current circle thanks to science and reforms. It is observed that the logo was removed in 142nd issue. After this issue, "Articles and Writers" part was added under the superscription and information about the content and content-formers of this issue was given. When the content of the journal is considered, it is seen that the part under the superscription was divided into three columns and this part was generally reserved for the leading article. Pages apart from the cover were also divided into three parts and articles, poems, stories, essays, reviews and biographies were published. Within the scope of the journal in which visual materials were also used, understanding of the articles was aimed by using aforementioned materials. In this term, photographs, illustrations (sketches) and other images were used in order to support the contents including statesmen, philosophers and artists, historical and artistic Works, researches in relation to space and art exhibitions, commemorative ceremonies or pageants in several cities, and other events.

The aim of publication of the journal of Hayat was stated within the main article in the first issue. The main article that was prepared by Mehmet Emin had the title of "For What Hayat is Published". The article, at the same time, reflected the publishing policy of the journal of Hayat. In the article, it was stated that no youth of any era had faced such a responsibility as much as the Turkish youth of contemporary and future era faced, and the great revolution created a Turkey on national and international basis; and the youth was encouraged for paying its debt back to the revolution. This debt, moreover, would be payable only through a conscious study that was procured for peace and felicity of Turkish nation. This consignment would feed its style and direction through science and knowledge. For this reason, according to Mehmet Emin, contemporary youth shall be equipped with an actual science and knowledge rather than the youth of any other era and the main aim of the journal of Hayat was stated as increasing the relationship between contemporary youth and sciences and encouraging the youth in the direction of arousing respect for science and knowledge. Therefore, the journal of Hayat would help the younger people to observe and think on the developments. Mehmet Emin, who explained that the youth shall be a beneficial and enlightened class who think about the events rather than acknowledging the concepts, also explained that the most important artworks of human beings is ideals, and the highest idea is the artworks. Moreover, he also announced that Hayat would serve for an increase in contact and satisfaction of youth in relation to art. Lastly, he stated that Hayat is not a property of anyone, it belonged to the intelligent, and therefore, it would gain power by them and reflect their mutual ideals. According to Emin, "Hayat" would not be mortal just as peculiar life just because it serves in this direction. (Mehmet Emin, 2 Kanun-u Evvel 1926,p.1-2).

Within the content of Hayat which was introduced as a journal of science, philosophy and art; issues that are important in the name of founding a new nation such as Republic, reforms, scientific issues, development idea in art, science, knowledge and economy, nationalization, modernization were discussed, and duties of intellectual in this way were mentioned. Among the persons who frequently produced content for the journal, there were names such Mehmet Emin, Nâfî Atuf, Fâruk Nâfiz, Köprülüzade Mehmet Fuat, Fazıl Ahmet, Mustafa Şekip, Mehmet İzzet, Ahmet Refik, Reşat Nuri, Avni, Ali Canip, Kemal Şakir, İsmail Hüsrev, Şukufe Nihal, Halil Fikret and Necmettin Sadık. The journal of Hayat continued its broadcast life with a different content and form by the publication of its 146th issue. Within the scope of the article with the title of "Hayat" that was published in 146th issue, it was stated that there was a large need for intellectual selection and high levels of knowledge, and intellectual had been searching a way for developing their knowledge levels. In the article through which the fact that Hayat would change its publication policies was explained, it was also stated that a journal that would only meet the needs of intellectual class but that would not attend to any area of specialization would be published. Hayat, which would be published for higher literary men and philosophers, carried the intention of encouraging the intellectual for the innovative writing. Along with this, Hayat would also be changed in terms of form. It was stated that it would be published on monthly basis, and it would include 100 pages. The maintenance of the journal's existence which is presented as an idealist journal was attributed to the existence of the Republic. In this context, it was stated that Hayat paid court to Veteran Soldier Mustafa Kemal through the article (Hayat, 30 Kanun-u Evvel 1929, p.1-2). The broadcast life of the journal of Hayat was ended after 5 innovative issues were published in 1930s. 


\section{THE ROLE OF THE JOURNAL IN THE FACE OF REFORMS}

According to the journal of Hayat the content of the reforms that trigger the great transformations experienced by Turkey, which were also followed and appreciated by the West, was not understood out rightly. It is understood through the inspected writings that the journal had the goal of introducing the reforms both at home and in foreign countries. According to the journal, what lacks and what shall be done was the lack of revolutionary ideals of the new generation and the fact that sufficient information was not provided in terms of the reasons and aims of the reforms. Mehmet Emin, in his article titled as "Our Mission in Introduction of Our Revolution", stated that in order to acknowledge the direction of the revolution, it is necessary to acknowledges social elements. Emin stated that contemporary generation may be able to feel the revolution just because it is living in it, however feeling will not be able to understand or explain the revolution. According to Emin, the most important thing to do is to think about the aims and reasons of what is felt, and to reveal those reasons within the scope of a certain system (Mehmet Emin, 12 May 1927, p. 461462). In terms of infusing the reforms, Mehmet Emin attracted the notice of the role of governesses in growing revolutionary ideals. An uphill and down dale education was expected, in other words; the education of the ones who will educate the society, and transference of the ideals by the teachers and academicians who received their education with "revolutionary ideals" to the new generations was expected. Emin mentions this duty of educators as "governesses who are obliged to infuse contemporary ideals to prospective generations" (Mehmet Emin, 12 May 1927, p. 461-462). Secondly, Emin mentioned the duties of Ottoman Universities in terms of those reforms. First of all, Ottoman Universities shall explore the reasons and purposes of the Turkish reforms within the scope of a certain system. According to Emin, there is nothing beyond the orations of the Veteran Soldier's that reflects the supreme spirit of Turkish nation in terms of Turkish reforms; and the alleviation of this lack is the mission of Ottoman Universities. Emin suggested that the Ottoman Universities shall explore recent changes and transformations of Turkish nation step-by-step and follow the ideal movements for revealing the reasons behind them (Mehmet Emin, 12 May 1927, p. 461-462).

In another article with the title of "Concept on Revolution and Hayat" which was published within the scope of the journal, it was stated that the person, after being generated by his / her mother and father, also becomes generated in a community, and the Turkish intellectual community gets born for three times who are sophisticated within Independence Warfare and reforms. Under the contemporary conditions, it was explained that it was necessary for the new generation to differ from the intellectual community of the last phases of Ottoman Empire, and to have a world of ideas that transforms into "secular" point of view from "ethereal" point of view. Likewise, this new life is actually is a tool for ethereal felicity (Mehmet Emin, 12 May 1927, p. 461-462). The journal of Hayat defended the idea of "individualism" or as it was called in the articles "the concept of individualism" in orders to provide a new society order, within the scope of this framework. In a new order of society, abilities and efforts of the individuals would be considered. A comparison between democracy, absolutism and constitutionalism was performed, and it was stated that salvation of Turkish nation that had become a colony of imperialist states in economic field would only be possible through the efforts and struggles of the individuals that share the same (Hayat,1 Teşrin-i Sani1928, p.445).

In the journal, another concept that went hand in hand with "individualism" was "nationalism". According to the journal, one of the most important features of the new society was the fact that it was a "national society". The viewpoint of "nationalism" that was integrated to "individualism" was explained through the necessity of individuals believing in the power of himself/ herself and his / her nation. According to this, both individuals and nations get sophisticated within the borders of struggles and difficulties. Again, by showing Italy in Renaissance, the facts that Italy had a sectional structure and its government was not strong, it was stated that the necessity of being powerful in life was brought for the individuals (Mehmed Emin, 23 Kanun-u Evvel 1926, p.61-62). Additionally in the journal, it is also observed that social, economic and legal changes were also mentioned in order for obtaining a new order of society in five years within the scope of Republican ideology. Clearly, a comparison between "old" and "new" was procured in the journal, and the source of all problems were attributed to the old order and the religious mentality on which the old order based, and the new regime was depicted and presented as a savior. According to the journal, the Republican ideology different from the "old order" - moved Turkish nation closer to the level of Western national states and removed the bars that are in front of development of Turkey on ideal, economic and social fields. Again within the scope of the journal, the most important factor that prevented Turkish nation from moving forward was presented as religious mentality which promoted "superstitions and traditions". Therefore, according to the journal, religion in social life turned back to its place where it should have always been along with the introduction of Republican ideology. The regime of Republic separated the religious issues and governmental issues from each other, pursuant to the legal provinces that were also brought by the new regime (Hayat, 1 Teşrin-i Sani 1928, p.445). 


\section{REFORMS AND THE PROGRESSION}

Within the scope of the journal, it was mentioned that there is a strong relationship between improvement in science, economy and art and reformism. First of all, the relationship between science and reformism, and the necessity of identifying the condition of reform for science and science for reform were stated. According to the journal, the most important role of the sciences in the face of the direction and movements of live and communities was to follow them by giving importance to each new manifestation and enlarge their cognizance areas. Revolutions are quite dynamic movements. They shall be performed consciously by the beginning and until the end. There are various reasons behind the reforms; the strongest one of them is humanity. Successful revolutions are strong guidance. According to the journal, it is not possible for revolutionary guidance to move without sciences by means of directing a large human mass to a new direction. If sciences are the productions of people's previous experiences, no revolution can be performed without sciences. In reforms, it is not correct to give importance to religion more than the amount that it deserves. Moreover, industrial revolution which is the biggest revolution of humanity was also embodied by the sciences. Turkish revolution, moreover, performed under the influence of science and philosophy. According to this, just having information does not make a person have knowledge. The information shall be made philosophical; and shall be based on contemplation and willpower (Avni, 16 Kanun-u Evvel 1927, p.41)

Within the scope of the article that was prepared on the occasion of the latest declaration of deputy of education after his investigation travel to Europe, Köprülüzâde Mehmet Fuat mentioned the importance of science and art institutions in a new civil development and he highlighted the steps of government that were taken in this direction. Mehmet Fuat declared that scientific and artistic institutions will be founded that will worth the honor and power of Turkish nation, such as universities, museums, national libraries, national theatre, etc. Mehmet Fuat also stated that the nation would not also avoid from necessary sacrifices, a new development phase would be started after aforementioned changes had been procured, and therefore Ankara would not only be the political center of Turkey, but also would be a center of knowledge (Köprülüzade Mehmet Fuat, 7 April 1927, p.361-362.) Along with this, thought that the steps that were taken towards were insufficient. According to Fuat, Turkish nation was still poorer than the other nations in terms of scientific and artistic institutions. Fuat claimed that period of autocracy did not give value to such institutions and national culture just for the devastation of each attempt in this direction. According to Fuat, nothing big was also performed in Constitutional Period. Although studies began in Republican Era, there were still not any public libraries, a national theatre, museums, national treasure, and scientists who specialized in the fields of archeology and ethnography. Except for a couple of exclusions, institutions in those fields remained in a primitive form (Köprülüzade Mehmet Fuat, 7 April 1927, p.361-362).

Mehmet Fuat thought that Turkish intellectuals should also perform their duties in terms of science and knowledge. According to Fuat, establishing universities in Anatolia is an irreplaceable mission of Turkish intelligentsia. Fuat also emphasized that while founding these institutions, a priority shall be given to the necessity of establishing these institutions in a way that was equal to the levels of contemporary civilizations in physical and spiritual terms (Köprülüzade Mehmet Fuat, 7 April 1927, p.361-362). Within the scope of the journal, the necessity of having sufficient equipment and knowledge in establishing a new society was highlighted along with the fact that the subjects of science and reforms were important, and the necessity of physical and spiritual conformation of scientific institutions that were equal to contemporary civilizations were emphasized. It was explained that within Ottoman society before the regime of Republic, even statesmen had not have enough scientific knowledge and that was presented as the reason why the community was not able to get developed. Another example of this situation may be the article with the title of "Recognizing a Country". Within the scope of the article, the contemporary situation of Turkish nation covered the persons who were included at the top-level part of the state such as the grand vizier. The illiteracy and shock of the grand vizier in the face of Russian armada that came to Beşike Harbor was given as an example. Therefore, "recognizing a country" which is also the title of the article constitutes "having knowledge about the materialistic tools that will push the country forward." In the article, it was stated that the generation that intended to re-establish the country was not able to procure agricultural productions just because they did not have any information about the geology or climate of the territory on which that they led their lives. It was stated that they were not able to found a factory when they attempt to establish a new economical source just because they don't have sufficient knowledge in this field. In the following parts of the article, meteorology, agricultural institutions and Turkish study institutions were suggested in order to inform the individuals about scientific areas (H.M., 8 Teşrin-i Sani 1928, p.465).

On the other hand, the recession in terms of intellectual areas, from literature to philosophy and fine arts, was discussed by the important intellectual people of the era in the journal. According to the authors of the journal of Hayat, main reasons behind the fact that sufficient improvements were not current in scientific and 
intellectual terms were listed as the lack of ideal of working for ideas and sciences, unsuitability of economic condition of the country, scientific discussions and artworks were the ideas and artworks of other countries and scientific studies were not sufficiently encouraged. All of these discussions were presented by Mehmet Izzet within the scope of his article titled as "What is the Reason Behind the Recession in Our Intellectual Life?" According to Mehmet Izzet, these reasons that were listed below were not sufficient. Izzet rejects the idea that the ministry of education had performed enough materialistic encouragement for intellectual and scientific improvement and the idea that science did not improve due to financial insufficiency or economic conditions. Again, according to Izzet, poverty is not an obstacle for an improvement in intellectual area. Izzet showed the famous men of letters, thinkers and craftsmen who had economic problems as examples and claimed the idea that financial problems could not become an obstacle for their skills. Moreover, according to Izzet, excessive freedom and wealth lead human beings to laziness and indifference (Mehmet İzet, 10 Kanun-u Evvel 1928, p.41-42). According to Mehmet Izzet, the actual reason behind the fact that the number of great skills both in fine arts and philosophy was low was not in relation to financial and economic conditions, but in relation to social, i.e. political conditions. According to Izzet, like each ideology, political ideologies did not free the skills that they were not able to bind themselves. Izzet, by showing Ziya Gokalp as an example, stated that Gokalp spent the most of the Party of Union and Progress for military issues and could not find any time for poetry and philosophy, otherwise Gokalp could have legated much more valuable poems and philosophical artworks for Turkish nation. On the other hand, Mehmet Izzet emphasized the low number of intellectual works at the time of large change and transformation period that was experienced on political and social areas. Izzet, who stated that fields of literature and art were sleeping at the time of French Revolution, emphasized the fact that intellectual productions that were obtained at the times of large reforms or reforms had less insignificance or low amounts. According to Izzet, if there was a grain of truth in his statement, important ideals and artworks would be possible in the future. Years that follow a big revolution or a great reform may bring valuable artistic and idealistic works along with themselves as a gift (Mehmet Izzet, 10 Kanun-u Evvel, p.41-42).

\section{IN THE FACE OF CONTEMPORARY AND PRIVATIVE INTELLIGENTSIA}

A new ideal of intelligent was tried to be obtained by performing the criticism of intelligent through "old" and "new comparison within the scope of the journal of "Hayat. In the journal, while the government and administration of the period before Republican regime was depicted as "Middle Age Mentality" that prevented the nation and the country from improvements, that enslaved the nation to empty, ominous habits; it was also stated that Turkish Nation made a movement through the middle of twentieth century thanks to the consequences of the reforms (Halil Fikret, 16 August 1928, p.226-227). In this context, "new intelligent" who was to be raised in contemporary institutions in accordance with new reforms' mentality was considered as beyond the illiterate and underdeveloped intelligent of the previous period, and it was valued more. Mehmet Emin who compared and contrasted the old intellectual and the new intellectual defended the idea that a series of parties hadn't known Westernization as an ideal and they only imitated the idea of Westernization. Emin, by highlighting the fact that the new generation was also westernized, emphasized the intention of creating an intelligent civilization within the country, and giving priority to the direction of this kind of civilization (Mehmed Emin, 23 Kanun-u Evvel 1926, p. 61-62). Moreover Köprülüzâde Mehmet Fuat stated that each administration system had its own distinctive operation system and Ottoman Empire had also its own administration system, within this system, the society was abused because the sultan and servants got integrated with muslim theological schools. According to Fuat, especially preventing from free discussion caused the society to become illiterate (Köprülüzade Mehmet Fuat, 30 February 1927, p.181-182). However according to Fuat, National Republican Administration completely based upon science and knowledge, addressing at the whole mutual benefits of the society instead of only privileged classes. Substitution of contemporary constitutions and conceptions, discussion of each idea in a free direction were the features of current system. According to Fuat, the most basic feature that differentiates the new intellectual from the old intellectual was the fact that the intelligentsia of National Republican administration shall come from the inside of the community, they shall be equipped with national culture and national goals, and shall actually be modernized and European. On the other hand, Fuat stated that while the scholars who were raised in older Ottoman Empire Schools served in accordance with the pleasures and directions of the sultan, scholars who were raised in compliance with today's reform ideals were aiming at establishing the dominance of actual science and knowledge at every level of social lives (Köprülüzade Mehmet Fuat, 30 February 1927, p.181-182).

Along with this, the typecasting of "contemporary man" and "privative man" were remarked among the writings inspected, seeming as a member of intelligentsia but not in compliance with the type of the intellectuals which were expected by the revolution. While "contemporary man" represented the "wannabe European" intellectuals who pretended to be Western with an admiration of Westernization, "Privative Man" 
represented the intellectual who always in an opposition with each kind of reform. According to this, "contemporary man" was one of the types rooting from Tanzimat Era. When Ottoman intellectual established a close relationship with Europe during Tanzimat Era, it was also seen how much lack was present within the scope of civilization area. As a result of this situation, a crew of intelligentsia who immediately adapted to Westernization was originated. Privative man was deemed as a member of enlightened class. However he had a specific meaning for enlightened ideals. One of the most important features of being enlightened, the love for science and knowledge, was unimportant for them. They also ignored the efforts of westernization for science. They preferred to complete sophisticated departments of education and they aimed at learning languages in order for leading the life that they had desired. Even they were using foreign words when they were speaking Turkish (Osman, 27 Kanun-u Sani 1927, p.173).

Contemporary men did not have national senses in their hearts, they used to run towards sophisticated arms of foreign circles without recognizing their own individualism, language and national lives, got modernized in a way that was away from their national feelings and got Europeanized. The soul of contemporary man used to be similar to department stores; however they used to get collapsed in consequence of a very small quandary. They carried their words, ideas, attitudes in a provisory way. Their biggest desire was to dress like an American and lives like English. They were displeased with all scientific, political and administrative structures of Turkey, and they wanted to be in Europe. According to contemporary man, Turkish architecture, art and literature were lost just as China's and was not worth for getting improved. Like this, they didn't read Fuzuli, they didn't know the most important cities of Anatolia, and they didn't get excited in the face of national developments. However they were able to mention an event that had happened in America or a development in English history. A new thing, especially if it is bright and sophisticated, could attract his attention immediately. Contemporary men used to get affected by Westernization without recognizing the fact that it was attacking all over our country in the days of war (Osman, 27 Kanun-u Sani 1927, p.173).

Moreover with the concept of "privative man", the man who got unfortunate in consequence of each reform that was taking place within the community. Privative man used to oppose just for having an opposition. He always understood all properties and developments through its reverse. For him, the brightest results of reforms were a kind of toy; the most sincere purposes of improvements were meaningless. The privative man was sincere and serious in his ideas. They used to reveal the brightest events of the history that consisted of one thousands of pages just for proving their claims. They used to make comparisons and contrasts but they used to have bias in their thoughts. They were always in crisis both by physical and spiritual means. They used to resist reforms, and they used to suffer from flaming quakes of reforms periods. They used to remain under the pressure of society and they used to accuse the complete of community. Privative man used to observe themselves as sacrificing representatives of previous social institutions. They frequently stated that the long road which was left behind would guide us to the truth, manners, traditions, clothes and forms would not be able to be changed (Osman, 16 Kanun-u Evvel 1927, p.52).

In the article with the title of "Coronation and Marriage", moreover, the intellectuals or seem-to-beintellectuals who accepted each innovation without any question or discussion were criticized for being Greek to other countries and their regimes, traditions, life-styles. In the article, just like Western countries that once used to find the cassock and turban strange, Turkish intellectuals began to find the other nations' traditions in way resembling taking a revenge of the past. So much so that, while a daily journal introduced news about coronation in Japan, the words of "coronation and marriage" (Coronation is tetevvüç in Ottoman Turkish, and marriage is tezevüccü in Ottoman Turkish) were confused with each other. Again, within the scope of the article that criticizes the echoes of the news about coronation of Japan in a started and shocked manner, it was reminded that Ottoman territories used to have the same celebrations in the days when Sultanate was the current regime (Hayat,15 Teşrin-i Sani 1928, p.504).As it can be seen until this point, a criticism of "intelligentsia" was made who penetrated to the general of society from Ottoman to Republic, negative intellectual stereotypes were mentioned. In the inspected articles, it is seen that the journal of Hayat placed "intellectuals with ideals, reformist and equipped intellectuals" in the place of this out-fashioned and negative types of intellectuals. The reformist intellectual was represented as a person who had the "reform ideals" that would make the society run and even leap in terms of improvement, and a person who would accustom the dark souls to the duties of reforms as well as taking precautions in delivering the reforms to the darkest mentalities. According to the journal, it was stated that "reformist intellectual" shall have the feature of being open to new thoughts and ideals no matter how strong and resistant the previous habits of the regime (Halil Fikret, 16 August 1928, p.226-227).

\section{CONCLUSION}

There were two suggested ways within the scope of Hayat with the aim of introducing the reforms both inland and on abroad. In the journal, foundation of universities that would research the reasons and results of 
the reforms was seen necessary and inspection of changes and transformations of Turkey within the last century shall be procured within those universities, firstly. Secondly, it was found necessary to deliver "reform ideals" to the youth. Within the scope of the journal which especially highlighted the role of educators in raising young generations, education shall be formed in accordance with the ideals of contemporary era.

Thanks to the steps that were taken with New Republic, the journal indicated the fact that Turkish Nation was born for the third time, and reforms were depicted as a transformation period that was experienced after the War of Independence as a whole. In the journal, "positivism", "individualism" and "nationalism" which were observed as three important components of modernization and that reflected the dominant cognitive environment of the era were the center of this transformation period. It was stated that the Turkish society, through which the "new" and the "old" were compared and contrasted, went into a new order of society in the direction of the reforms and this order shall be led by rationalism, basing on individualistic efforts and owning a nationalist structure. The condition of society before the reforms was depicted as "rudimentary and underdeveloped"; and the responsibility of not being able to get improved in terms of science, economy and knowledge was laid on the older order of society which was formed with a religious mentality. In the journal, in compliance with the dominant positivist paradigm of the period, a mentality consisting of "superstition and traditions", "basing on fatalism" was not sufficient to fulfill the purposes of an earthly life. Therefore, it was thought that the concept of "religion" turned back to where it belonged from then on with a mentality which was going through secularization.

On the other hand, it was stated that there was a belief in the direction of the fact that depending on "the power of individual" and "what individuals do" within the scope of the new order of society, the society would be able to develop in terms of economy and scientific area. Each individual, within the scope of this new society order, would be obliged to protect his / her national values, work steadfastly and unselfishly for a mutual goal of aggrandizing his / her culture and civilization. According to the journal, one of the most important characteristics of the new society is its being "a national community". In this context, a society that include self-sufficient and hardworking individuals who were raised with national ideals was imagined.

As far as the inspected articles showed, it was observed that titles such as "reform and improvement in science and knowledge", "bringing revolutionary manners for the youth", "obligations of intelligentsia in establishment of a new order or society" were originated. First of all, the necessity of having sufficient equipment and information in establishment of a new society was highlighted and the young people to be raised in related institutions were expected to be raised as having "information about financial tools to reestablish the nation". The authors of the journal of Hayat rejected the theories in the direction of the idea that the state did not encourage and maintained intellectual art works as a reason for not being improved in terms of science and knowledge. While Mehmet Izzet indicated great change and transformation periods that were experienced on great political and social areas as a reason for stability of intellectual fields, Köprülüzade Mehmet Fuat saw the fact that there were not institutions in Turkey that were equal to the levels of Europe in materialistic and moral terms as responsible. Additionally, it was also expressed that it would not be adequate to establish new institutions in relation to science and knowledge all around the country. It was also expected that the educators who would undertake roles in those institutions shall also meet certain qualifications. In this context, the ones to serve education in those institutions were to be chosen among the people who developed their spirits in their academic journeys, beginning from assistance to the level of being a professor, who devoted their lives to certain purposes.

Within the frame of the journal of Hayat, another important title in relation to education was "bringing revolutionary morals to young people" for the following articles. Due to the fact that youth was seen as the people who would organize the future, a generation that was raised with the manners of reforms was seen necessary in order for penetration of reforms into each layer of the society. In the journal, it was emphasized that the most important thing in raising a generation was to bring in a purpose for them. Additionally, the youth would give up old traditions such as "believing" or "being made believe"; and an education through which the idea of that a new thought would be able to replace the old done would be served for them. Therefore, the thing that determine the quality of the education which was given to the youth in universities shall not only include non-sensing information about the concept, but shall include the idea that they would be able to get encouraged for new viewpoints and experiences through new readings. Lastly, it is also seen that within the scope of the journal, a comparison between the old and new type of intelligentsia was held through the concepts of "contemporary and privative man" and the negative characteristics of intellectuals were highlighted, and the "new intellectual" type which was brought by Republic was praised. 


\section{REFERENCE LIST}

"Bir Bilanço", Hayat, 1 Teşrin-i Sani 1928, C.4, Sayı: 101, s.445.

"Harfler Kanunu", Hayat, 1 Teşrin-i Sani 1928, C.4, Sayı:101, s.484.

“Tetevvüç ve Evlendirmek”, Hayat, 15 Teşrin-i Sani 1928, C. 4, Sayı: 103, s.504.

Atatürk'ün Söylev ve Demeçleri. (1989). Ankara Üniversitesi Türk İnkılâp Tarihi Enstitüsü Yayınları, Cilt:1, Ankara.

Avni, "İlim ve İnkılâp”, Hayat, 16 Kanun-u Evvel 1927, C.1, Sayı:3, 41.

Faruk Nafiz, “Kumun Üstüne Mısralar”, Hayat, 19 Ağustos 1928, C. 4, Sayı: 90, s.232.

Gökberk, M. (1997). Aydınlanma Felsefesi: Devrimler ve Atatürk, Cumhuriyet Yayınları. İstanbul.

H.M., "Memleketi Tanımak", Hayat, 8 Teşrin-i Sani 1928, C.4, Sayı: 102, s.465.

Halil Fikret, "Münevverler ve İçtimai İnkılâbımız", Hayat, 16 Ağustos 1928, C.4, Sayı:90, s.226-227.

Hayat, 19 Temmuz 1928, C. 4, Sayı: 86, s.162.

Hayat, 15 Temmuz 1929,C. 6, Sayı: 135, s.23.

Hayat, 19 Ağustos 1928, C. 4, Sayı: 90, s.232.

Hayat, 30 Eylül 1929, C. 6, Sayı: 140, s.15.

Hayat, 30 Kanun-u Evvel 1929, C. 6, Sayı: 146, s.1-2.

Koloğlu, O. (2006). Osmanlı'dan 21. Yüzyıla Basın Tarihi. Pozitif Yayınları. İstanbul.

Köprülüzade Mehmet Fuat, “ilim Müesseselerimiz”, Hayat,5 Kanun-u Sani 1927, C.3., Sayı: 58, s.101-102.

Köprülüzade Mehmet Fuat, “İnkılaba Karşı Vazifemiz”, Hayat, 30 Şubat 1927, C.1, Sayı: 10, s.181-182.

Köprülüzade Mehmet Fuat, "Müstakbel İlim ve Sanat Müesseselerimiz”, Hayat,7 Nisan 1927, C. 1, Sayı:19, s.361-362.

Mehmed Emin, “İnkılap ve Hayat Hakkında Telakki”, Hayat, 23 Kanun-u Evvel1926, C.1, Sayı: 4, s.61-62.

Mehmed Emin, “Kuvvetli Münevver Zümre Nasıl Yetişir?”, Hayat, 6 Kanun-u Sani 1927, C.1, Sayı:6, s.101102.

Mehmet Emin, “Dağ Yolu”, Hayat, 20 Eylül 1928, C. 4, Sayı: 95, s.325.

Mehmet Emin, “Hayat ne için çıkıyor”, Hayat, 2 Kanun-u Evvel 1926, C. 1, Sayı: 1, s.1-2.

Mehmet Emin, "İnkılâbımızı Tanıttırmak Hususunda Vazifemiz”, Hayat, 12 Mayıs 1927, C.1, Sayı:24, s. 461462.

Mehmet İzzet, "Fikir Hayatımızdaki Durgunluk Neden?”, Hayat, 10 Kanun-u Evvel 1928, C.3,Sayı:55, s.4142.

Osman, “Asri Adam”, Hayat, 27 Kanun-u Sani 1927, C.1, Sayı:9, s.173.

Osman, "Menfi Adam”, Hayat, 16 Kanun-u Evvel 1927, C.1, Sayı:9, s.52.

Topuz, H. (2003). Türk Basın Tarihi. Remzi Kitapevi. İstanbul. 